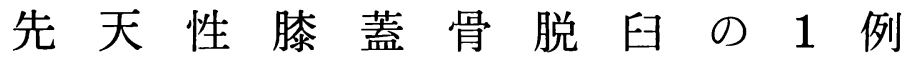

清水整形外科病院

清 水 正 章・嘉 悦 博
板 倉 和 資

\section{A Case Report of the Congenital Persistent Dislocation of the Patella}

by

\author{
M. Shimizu, H. Kaetsu and K. Itakura \\ Shimizu Orthopaedic Hospital
}

\begin{abstract}
A case of a 19-year-old girl with bilateral congenital persistent dislocation of the patella is reported.

The patient was operated by Hauser and Campbell method on the left knee.

Two years and three months later, clinical and subjective assessment is satisfactory.
\end{abstract}

わが国における滕蓋骨脱臼の報告はまれではない が，大多数は習慣性脱臼であり，しかも外傷に起因す るものが多く，恒久性脱田てついての報告は甚だまれ である．膝蓋骨脱臼の成因，分類については，古くか らさまざまの報告があり，さらに観血的療法について あ問題点が多く，未だ結論をみず未解決の分野が残さ れているのが現状である.

今回, われわれは家族性汎発性関節勒帯弛緩を伴。 た両側性先天性恒久性滕蓋骨脱臼の 1 例を経験し，愁 訴の強い左膝に対し Campbell 法に Hauser 法を併 用した手術を行ない，術後 2 年以上経過した現在良好 な結果を得ているので報告する.

\section{症 例 19 才女性}

主訴 両膝の 不安定と脱力感があり，ょく転倒す る.

家族歴 父と弟に膝の愁訴があり，父親には軽度の joint laxity と膝蓋骨の亜脱臼を認める. 弟は，直 接検診ができなかったが，15才で身長 $167 \mathrm{~cm}$ ，体重 $45.5 \mathrm{~kg}$ で発育は普通であるが，ひ弱な感じで膝の不 安定感があるため，歩容が悪くよく転倒することを問 診により確認した.

既往歴 特別のあのはない.

現病歴 幼少時から転倒しやすく，走力が著しく劣
っているため走るてとを苦手としていた．また，ょく 足関節を渝挫しており，昭和 52 年 5 月歩行中 足 関節 を捻挫し，外側勒帯損傷の診断で入院したが，同時に 全身諸関節の laxity と両㮏蓋骨の膝関節伸展位での 完全脱臼を認め, 同年 7 月 7 日手術を施行した.

現症 身長 $153 \mathrm{~cm}$, 体重 $50 \mathrm{~kg}$ と体格栄養とあに 中等で顔貌正常，中学での成績は，中の下位であっ た. 皮膚には, 異常伸展性, 脆弱性などの異常は認め られない，また，爪の変形はない。

検查所見一般臨床検查成績, 心電図, 脳波に特記 すべきことなく，筋電図す異常パターンを認めない。 出血傾向もない。

局所所見 両側手関節は背屈 $100^{\circ}, \mathrm{MP}$ 関節 $90^{\circ}$ 之 過度に可能なため, 前腕背側と手指背側とを他動的に 接することができる（図1)。 また，その他殆んどす べての関節に異常可動性が認められた.

膝前面の皮膚には，しばしば転倒しその際受けたと 思われる創痕がケロイド状に認められた，膝蓋骨は軟 部組織間に浮遊しているような感じで伸展位で外側方 に完全脱臼している，膝を届曲していくと両側とも $30 \sim 40^{\circ}$ で亜脱臼位に近づくが, $60^{\circ}$ 以上では再び外 方へ完全脱臼する. また，約 $20^{\circ}$ の過伸展之膝外反及 び下腿外捻が認められ，内側々副靯帯の弛緩があるた 


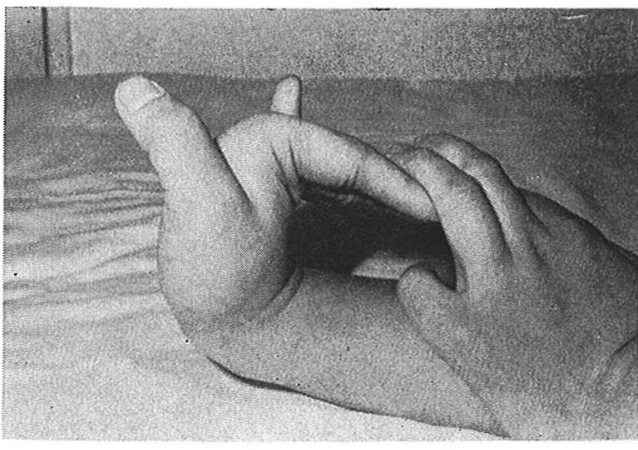

図 1

め側方動摇性は強い。

レ線上滕蓋骨は関節面が flatt で ridge が小さく, 顆間窩は浅くて外顆の形成不全が証明された．また， patella alta が認められる (図 2). 関節造影で内側 々副鞀帯の施緩が存在する. 以上より膝関節の可動制 限は見られないため，Conn のいう恒久性滕蓋骨脱臼 の定義よりやや外れるが, Stren, Stanisavljevic のいう脛骨外捻，膝外反，内側側副靱帯の弛緩を伴っ ているととと，膝蓋骨は関節の肢位運動に無関係俘外 側に脱臼していて，しかも自動的に整復不能であるこ
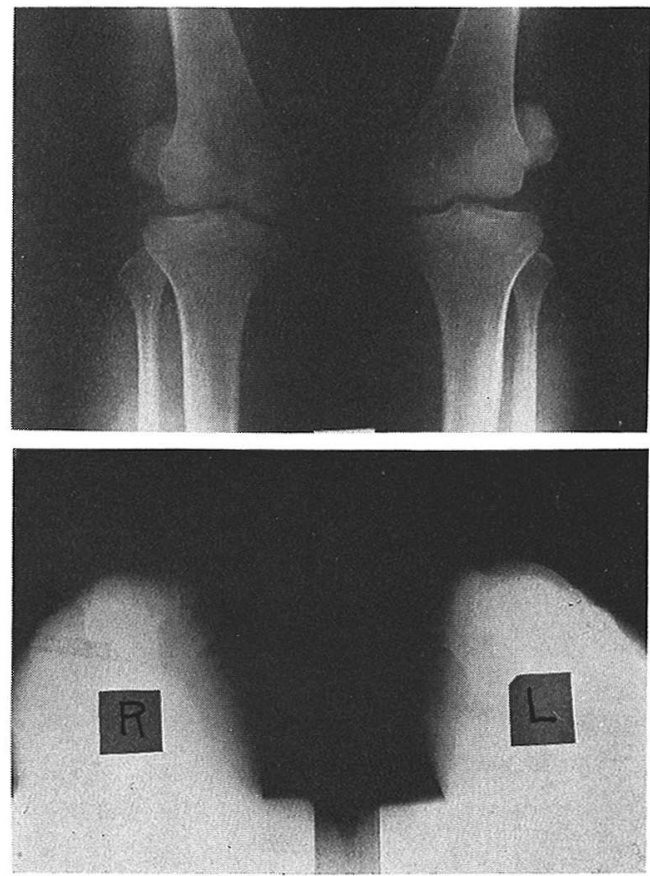

図 2
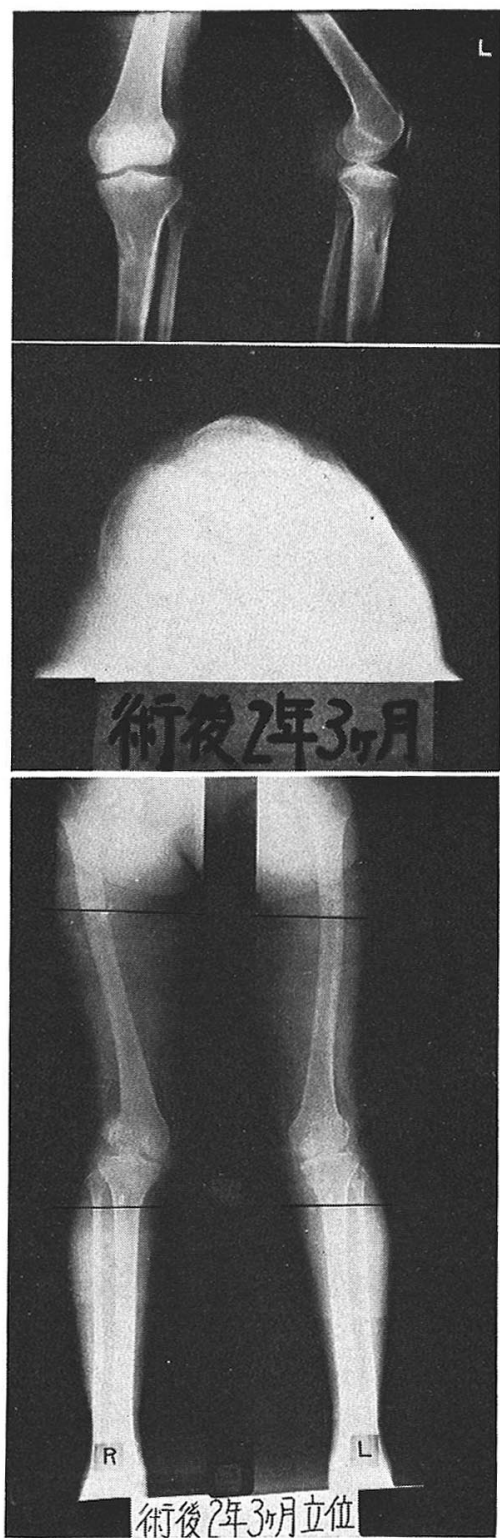

図 3

とから，恒久性脱臼と彰断した

治療

愁訴の強い左膝に手術を行ない，右滕は十分な muscle training を指導して, 特に手術的処置は加 えなかった。手術は Campbell 法に Hauser 法を併 用したが，膝蓋鞄帯は著しく延長し，大腿四頭筋は外 
側に脱臼している膝蓋骨とともに索状となって外側に 移動し, 内側広筋, 大腿直筋は萎縮している. 緊張し ている腸脛靱帯から膝蓋骨に達する薄い索状物があ り，てれが整復障害の一つともなっていた．また，脛 骨結節部は flatt で殆んど骨膨隆をふれなかった. 膝 蓋大腿関節は，平坦で軟骨に変性所見は見られなかっ たが，大腿骨外顆の形成不全を伴っていた.

脛骨結節を約 $1.5 \mathrm{~cm}$ 内方と下方へ移動させ，内側 の関節包の切除, 縫縮と Campbell 法に準じた Tenodesis を行なった. 術後は，ギプス固定を行な い, 4 週より自動運動を開始した. 術後 2 年 3 力月の 現在, 膝屈曲は非手術側之同様自動的に $155^{\circ}$ 可能で あり, 短時間ながら正座も可能で膝蓋骨の亜脱臼もみ られず, 十分な安定性を同時に得ている（図 3 ).

\section{考察}

習慣性膝蓋骨脱臼の歴史的背景 は, 古く, 遠く Hyppocrates 時代から知られていると言われている が，独立した疾患として知られるようになったのは， 1895 年 Appel, 1898 年 Steindler らの報告後であ る. わが国においては, 大正 11 年中村, 大正 15 年高 木らの報告に始まり, 以来諸家の数多くの研究業績 残されているが，未だに確立された治療法は見当らな い. 膝関節疾患において，最近特に注目されるように なってきた膝蓋大腿関節で，その主要部分である膝蓋 骨は，大腿四頭筋腱の中にある種子骨の一種であり， しかも他の種子骨と異なり，自動的に動かし得るもの である. 従って, 種子骨である膝蓋骨が脱臼したから といって，他の関節の脱臼とは病態を異にする. 即 ち, 関節の機能不全というより,むしろ大腿四頭筋の 機能不全という形で症状が現われてくる.

本症の成因については, 原因によって先天性之後天 性の 2 種類に分類されているが，両者を区別すること は実際上困難であり，既往に外傷が認められる場合で も，先天性素因が問題となる.

片岡は，文献上の考察から直接的原因之間接的原因 （表 1 ）に整理し，特に骨格構造よりあ筋機能の異常 を, 先天性要因として重視している.

Stren は, 腸脛靶帯の拘縮を指摘しており，また Baker, 腰野, 河野らは外側広筋とその周辺の結合織 化を重視している．素因としては，表 2 のような点が 指摘されているが，乙れらは何れあ複数以上の素因の 組合せによって発生するすのと考えられる.
表 1 片岡の分類 (1968年)

\begin{tabular}{|c|c|c|c|c|c|c|c|c|}
\hline 原 & & 因 & 脱 & 日 型 & 式 & 脱 & 白 状 & 態 \\
\hline $\begin{array}{l}\text { 先 } \\
\text { 後 }\end{array}$ & $\begin{array}{l}\text { 天 } \\
\text { 天 }\end{array}$ & $\begin{array}{l}\text { 性 } \\
\text { 性 }\end{array}$ & $\begin{array}{l}\text { 恒 } \\
\text { 習 } \\
\text { 再 } \\
\text { 不 }\end{array}$ & $\begin{array}{c}\text { 久 } \\
\text { 慣 } \\
\text { 発 } \\
\text { 定 }^{\text {定 }}\end{array}$ & $\begin{array}{l}\text { 性 } \\
\text { 性 } \\
\text { 性 } \\
\text { 性 }\end{array}$ & $\begin{array}{l}\text { 脱 } \\
\text { 爱 } \\
\text { 前 }\end{array}$ & $\begin{array}{l}\text { 脱 } \\
\text { 脱 }\end{array}$ & $\begin{array}{l}\text { 日 } \\
\text { 臼 } \\
\text { 甚 }\end{array}$ \\
\hline
\end{tabular}

本例は，父に joint laxity と膝蓋骨の亜脱臼傾向 があり，弟にあ問診により幼少時より膝の不安定感と joint laxity が確認できたとと，そして，患者の膝 蓋骨, 大腿骨顆部の形態及び膝蓋靶帯, 大腿四頭筋の 走行状態より，家族性先天性亡考えられた．わが国に おける家族的発生例は極めて少なく，特に本症のよう に父，姉弟の報告例には接しない，外国文献に先天性 膝蓋骨脱臼の家族的発生の多いのに比べて，わが国で の報告が少ないのは本例であそうであったように，家 系調査検索の困難性など民族習慣上の問題ああると思 われる.

岡崎らは, 関節靱帯弛緩症の 1 分症として, 先天性 膝蓋骨脱臼をとらえ, 中胚葉性の先天異常疾患 arthrochalasis multiplex congenita $の$ 軽症例とし て報告している. そして, 組織学的に関節包の弾性線 維の減少, 相対的な膠原線維の増加を述べているが, われわれの症例の組織所見からはこのような明確な答 えはでなかった。

表 2 先天性局所素因

1）滕蓋骨の発育不全及び大腿骨外顆の発育不全 (Giannelli)

2）大腿骨内 - 外顆間溝の発育不全（Micheal）

3) 膝外反 (Cole)

4) 大腿四頭筋の側方偏圧 (Micheal)

5) 膝関節の勒帯, 関節包の弛䋧及び数個の素因の 合成 (Sommer, Payr)

6) 胚芽異常 (Reineclse)

\section{治療}

先天股脱, 内反足のように早期発見早期治療が実際 上困難なため，殆んざすべて観血的療法である．手術 は，表 3 の如き方法に大別されるが，手術々式は古く から様々のあのが提案されており，その数大凡 100 種 以上にもなるといわれているが, Hauser 法に代表さ れる extensrn apparatus の realignment procedure が，考え方として妥当ではなかろうか. 何れに しても case by case であるが， 単一術式では十分 な成果を期待しがたく，2，3の手術法を合併するて 


\section{表 3 手 術的 療 法}
1）関節包形成術
2) 筋移行術
3）膝蓋鞄帯付着部移行術
4) 外顆形成術
5) 膝盖骨摘出術

とが必要である場合が少なくない，以上われわれは， 家族的汎発性靱帯弛緩を伴った先天性恒久性膝蓋骨脱 曰の 1 例を経験し術後 2 年 3 力月経過した現在, ほぼ 満足すべき結果を得ているので報告したが，今後膝蓋 骨の軟骨軟化の問題等について注意深く経過を見守っ てゆきたいと思う.

\section{参 考 文 献}

1) 安達: 整形外科, $17,376,1966$.

2) Balser, R. H. : JBJS 54-B, 103, 1972.

3) 古谷：整形外科, $15,337,1964$ '

4) 福林: 膝, 3, 37, 1977.

5) Hauser, E. D. W.: Surg, Gynecol, Obstet. 66, 199, 1938.

6) Hampson, W. G.: JBJS 57-B, 209, 1975.

7）羽生田：日整会誌， $12 ， 415$, 昭 12 .

8) 橋本：整形外科, 5,45 , 昭 29 .

9）菊地：日整会誌，14, 354, 昭 14 .

10）小寺：整形外科, $14,458,1963$.

11) 片岡: 整形外科, 19, 308, 1968.

12) 片岡: 臨整外科, 3, 222, 1968.

13) 河野：膝, 4, 171, 1978.

14）上川：日整会誌，5，259，昭5.

15) Madigan, R.: JBJS 57-A, 600, 1975.
16）牧野：整形外科と災害外科，25，34，1976。

17）中村：日外会誌, 23,508 , 大 11 .

18）扼田：整形外科， 7, 401, 1956.

19）岡崎：整形外科, 25, 1019, 1974.

20) Storen, H.: Acta Orthop. Scand. 36: 301, 1965.

21）高木：日整会誌， $5 ， 259$ ，昭 5 .

22) Williams, P. F.: JBJS 50-B, 278, 1968.

23）山本：関東整災誌，9，156。1978.

質 問福岡赤十字病院 上崎 典雄

反対側を手術されておられませんが，何か理由があ ったのでしょうか.

解 答 清水整形外科病院 清水 正章 術後 $\mathrm{ADL}$ の改善著しいためとくに反対側への手術 侵襲は考えていない.

解 答 清水整形外科病院 清水 正章

1. Hauser 法における脛骨結節のひきさげについ ては case by case であるが，余りひきさげすぎる と pressure のため chondromalaia あるいはOA 様変化の発生又は增強をみるので手術時脱臼が起こら ぬ程度にひきさげておけばよい，私の場合約 $1.5 \mathrm{~cm}$ のひき下げであった.

Harrison は術後のOA様変化の進行はみられぬと しているが, Macnab は逆に一旦起こった変化は術 後も進行すると述べている. 今後軟骨軟化の発生に注 意してゆきたいと思う. 